\title{
Potential of Cinnamon (Cinnamomum Cassia) as an Anti-Oxidative and Anti-Microbial Agent in Sudanese Yoghurt (Zabadi)
}

\author{
Alia H. Suliman ${ }^{1}$, Khogali E Ahmed ${ }^{1}$, Babiker E Mohamed ${ }^{1}$ and Elfadil E Babiker ${ }^{1,2 *}$ \\ ${ }^{1}$ Department of Food Science and Technology, Faculty of Agriculture, University of Khartoum, Shambat, Khartoum North, Sudan \\ ${ }^{2}$ Department of Food Science and Nutrition, College of Food and Agricultural Sciences, King Saud University, Saudi Arabia
}

Submission: May 03, 2019; Published: May 31, 2019

*Corresponding author: Elfadil E Babiker, Department of Food Science and Technology, Faculty of Agriculture, University of Khartoum, Shambat, Khartoum North, Sudan

\section{ABSTRACT}

This study evaluated the biological efficacy of cinnamon powder (CP) from Cinnamomum cassia in cow milk yogurt. CP had a total flavonoid and phenolic content of 132.87 and $818.73 \mathrm{mg} / 100 \mathrm{~g}$, respectively. CP exhibited significant free radical scavenging properties with antioxidant activity clearly correlated with CP concentration. CP extracts, especially the methanolic extract, produced large inhibition zones against pathogenic bacteria, comparable to that of penicillin. Yogurt $(0.5 \%$, and $1.0 \% \mathrm{CP})$ was refrigerated for 7 and 14 days. CP increased total yogurt solids with no effect from storage. Titratable acidity, $\mathrm{pH}$, and lactose content significantly decreased with storage and $\mathrm{CP}$ concentration. Total bacterial, coliform, and $E$. coli counts significantly decreased with CP concentration. Lactic acid bacteria significantly increased with both concentration and storage. Sensory attributes following CP addition were rated slightly lower, except taste. Results indicated that cinnamon is effective against pathogenic bacteria, highlighting the possibility of processing yogurt with cinnamon.

Keywords: Cinnamon; Phenolics; Antioxidant activity; Sudanese yoghurt; Sensory attributes

\section{Introduction}

Herbs and spices have been used since ancient times, not only as antioxidants and flavoring agents but also for their antimicrobial activity against degradation caused by food-borne pathogens and food spoilage bacteria. Herbs and spices are rich in phytochemical antioxidants and among the top 50 foods with antioxidants, the top five antioxidants were dried spices [1]. Cinnamon has been known as one of the most common spices and food flavoring additives since ancient times. For instance, it has been used to flavor sweets and chewing gum due to its pleasant and refreshing sensory attributes. It also shows beneficial effects on oral health and is used for toothaches, oral infections, and to remove bad breath [2]. Cinnamon is mainly used in the aroma and essence industries owing to its fragrance, which can be incorporated into different varieties of foodstuffs, perfumes, and medicinal products. The most important constituents of cinnamon are cinnamaldehyde and trans-cinnamaldehyde, which are present in the essential oil, thus contributing to the fragrance and various biological activities observed with cinnamon [3].
Cinnamon significantly lower low-density lipo-protein (LDL) or "bad" cholesterol, triglycerides, and total cholesterol, and also reduces blood sugar levels in treating type 2 diabetes [4]. The considerable increase in demand for fermented milks observed in recent years has resulted, to a great extent, from consumer awareness of their beneficial effects. However, fermented milks are also highly valued for their unique taste and aroma, which also contributed to their growing popularity. Yogurt, produced by lactic acid bacteria (LAB), is one of the most popular fermented dairy products consumed globally. Moreover, it is more nutritious than many other fermented milk products since it contains a high level of milk solids in addition to nutrients produced during the fermentation process. Various types of yogurt are now available in markets, including stirred, set, frozen, liquid, and flavored yogurt [5]. Sudanese yogurt is mostly made from cow milk, with no added ingredients. The Processing of it is carried out at a local level and the procedure includes boiling and cooling of milk and inoculation with a 1-day-old previous batch of zabadi which serves as starter 
[5]. The milk and the starter mixture are then incubated at room temperature $\left(\sim 25^{\circ} \mathrm{C}\right)$ for $12-15 \mathrm{~h}$. The shelf life of the yogurt is limited to 3-4 days after processing and based on the favorable characteristics of cinnamon, this study aimed to evaluate the potentiality of cinnamon powder as an anti-oxidative and antimicrobial agent in extending the shelf life Sudanese yogurt.

\section{Materials and Methods}

\section{Materials}

Fresh milk was obtained from the University of Khartoum Farm. The milk samples were transferred in an ice box in a stainless-steel container and kept refrigerated until used to manufacture yogurt. Cinnamomum cassia bark was purchased from the local market, Khartoum North, Sudan. Cinnamomum cassia bark was ground to pass a $0.4 \mathrm{~mm}$ screen. All chemicals used in this study were of analytical grade.

\section{Preparation of $\boldsymbol{C}$. cassia extract}

C. cassia bark powder (5g) was extracted with $50 \mathrm{ml}$ methanol or water at room temperature $\left(24^{\circ} \mathrm{C}\right)$ for $12 \mathrm{~h}$ using an orbital shaker. The extract was then filtered and centrifuged (Hettich Zentrifugen, Tuttlingen, Germany) at 4000rpm for 10 minutes, and the supernatant was concentrated under reduced pressure at $40{ }^{\circ} \mathrm{C}$ for $3 \mathrm{hr}$ using a rotary evaporator (IKA-WERKE RV06ML).

\section{Total phenolics determination of $C$. cassia powder}

The total phenolic content was quantified using the FolinCiocalteu reagent (FCR) method as described by Madaan [7]. A gallic acid standard curve was prepared to evaluate the total phenolics in terms of gallic acid equivalents (mg GAE/100g) and the total phenolic content was expressed as mg GAE/100g.

\section{Total flavonoid determination of $\boldsymbol{C}$. cassia powder}

The colorimetric method described by Kim [6] was used to analyze the total flavonoid content of cinnamon using catechin as a standard. A calibration curve was prepared using catechin, and the results were expressed as mg catechin equivalents per gram of sample (mg CE/g).

\section{Determination of antioxidant activity of C. cassia pow- der}

The antioxidant activities of $C$. cassia bark powder were measured in vitro using three different complementary assays:

\section{1,1diphenyl-2-picrylhydrazyl (DPPH) radical scaveng- ing activity of $C$. cassia powder}

DPPH scavenging activity was determined using the method described by Lee [8]. A solution of DPPH in methanolic acid was used to assess the antioxidant activity of samples. The antioxidant activity was calculated as follows:

Antioxidant activity $(\%)=\left(1-A_{1} / A_{0}\right) \times 100$,

Where $A_{0}$ and $A_{1}$ are the absorbance of the control and extract, respectively.

\section{Total reducing power ability (TRPA) of $C$. cassia powder}

The TRPA of the sample was determined according to the method described by Oyaizu [9]. The TRPA of the powder at different concentrations was determined using vitamin $\mathrm{C}$ as a positive control, and the results were expressed as vitamin $\mathrm{C}$ equivalents.

\section{Hydrogen peroxide radical scavenging activity of $C$. cassia powder}

The hydrogen peroxide scavenging activity of $C$. cassia powder was determined using the method described by Jayaprakasha [10]. The percentage of $\mathrm{H}_{2} \mathrm{O}_{2}$ scavenging ability was calculated as follows:

$\mathrm{H}_{2} \mathrm{O}_{2}$ scavenging ability $(\%)=(\mathrm{Ab}-\mathrm{As} / \mathrm{Ab}) \mathrm{X} 100$,

Where $\mathrm{Ab}$ and as correspond to the absorbance of the blank and sample solutions, respectively.

\section{Production of Yogurt}

Raw milk was subjected to heat treatment $\left(70^{\circ} \mathrm{C}\right)$ for $\sim 20 \mathrm{~min}$, and then left to cool at room temperature $\left(25^{\circ} \mathrm{C}\right)$. A starter culture (1-dayold) from a previous batch of zabadi was added to the milk $(5 \mathrm{~g} / \mathrm{kg}$ milk), thereafter, mixed with different concentrations of CP $(0 \%, 0.5 \%$ or $1.0 \%)$ and then incubated overnight at the room temperature $\left(25^{\circ} \mathrm{C}\right)$. Part of the fresh zabadi was subjected to analysis and the rest was packed in plastic containers, closed tightly and stored for 7 and 14 days at $4{ }^{\circ} \mathrm{C}$. Samples were reanalyzed at the end of each storage period.

\section{Determination of Total Solids Content of Yogurt}

Total solid (TS) content was determined according to the modified method of AOAC [11]. The total solid (TS) content was calculated using the following equation:

$$
T S \%=\frac{W 2}{W 1} * 100
$$

Where $W_{1}$ and $W_{2}$ are the weights of the sample before and after drying, respectively.

\section{Titratable Acidity Yogurt}

The Titratable acidity (TA) was determined according to Bradley [12]. The percentage of lactic acid was calculated using the following equation:

$$
T A \%=\frac{m l(\mathrm{NaOH}) * N(\mathrm{NaOH}) * 9}{\text { WeightofSample }}
$$

where $\mathrm{N}$ is the normality of $\mathrm{NaOH}$ and 9 is the conversion factor for lactic acid.

\section{Lactose Determination of Yogurt}

Lactose (\%) was determined according to the method by Teles [13]. A standard solution of dry lactose in distilled water (\%) was used to determine the lactose content in treated and untreated yogurt using a colorimeter at $520 \mathrm{~nm}$.

\section{Antimicrobial Activity of Cinnamon Powder Extract}

The disc diffusion method by Boyanova [14] was used to assess the antimicrobial activity of cinnamon powder (CP) extract. 
Briefly, pure cultures of indicator microorganisms (Escherichia coli ATCC 10536, Salmonella typhimurium ATCC 14028, Bacillus cereus ATCC 14579, and Staphylococcus aureus ATCC 29737) were cultivated on nutrient agar plates. Paper discs saturated with aqueous or methanolic CP extract $(10 \mu \mathrm{g} / \mathrm{mL})$ were suitability positioned on the surface of the cultures and incubated at $37^{\circ} \mathrm{C}$ for $24 \mathrm{~h}$. Then, inhibition zones surrounding the discs were measured. Penicillin $(10 \mu \mathrm{g} / \mathrm{disc})$, a standard antibiotic, was used as a control.

\section{Microbiological load and pH of Yogurt}

The method of Harrigan [15] was applied to determine the microbial characteristics of yogurt at different periods of storage by plate count. Coliform bacteria count was carried out by using the Most Probable Number (MPN) technique. For S. aureus bairdparker medium was used. MRS medium was used for counting lactobacillus bulgaricus. The count of streptococcus spp. was done by plating the suitable dilution in M-17 agar. The plates were incubated at $37^{\circ} \mathrm{C}$ for 48 hours. Sample pH was determined with a pH meter probe (Corning Scientific Products, New York, USA).

\section{Sensory evaluation of Yogurt}

Panels of 20 semi-trained members (men and women between 20-35 years old) were asked to evaluate the sensory properties of treated and untreated yogurt on a 7-point hedonic scale. Prior to sample evaluation, three training sessions were carried to acquaint panelists with the attributes expected to be measured. Panelists were asked to evaluate the texture, flavor, color, taste, juiciness, and overall acceptability of each sample. Scores were measured from "like extremely" to "dislike extremely," corresponding to ratings from 7 to 1 , and tests were carried out three times at each evaluation interval $(0,7$, and 14 days). Mean scores for each sample and session were calculated.

\section{Statistical Analysis}

All measurements were carried out in triplicate, and three batches of yogurt were produced. The effect of CP on parameters was analyzed statistically using SAS software (v 8.1, SAS Institute Inc., Cary, NC). Data on the parameters measured based on various treatments, storage periods, and their interactions were analyzed using the general linear model (Two-way ANOVA), and statistical differenvces were estimated using Duncan's multiple range tests. Mean separation was determined using least significant difference, and data are reported as the mean \pm standard deviation (SD). The significance level was accepted at $\mathrm{P} \leq 0.05$.

\section{Results and Discussion}

\section{Total Phenolics, Flavonoids, and Antioxidant activity of CP}

The total phenolic content, flavonoid content, and antioxidant activity of CP are presented in Table 1 . The total phenolic content of CP was found to be $818.73 \mathrm{mg} \mathrm{GAE} / 100 \mathrm{~g}$. This result was higher than that reported by Kumar and Prakash (2012) for Cassia fistula and C. cassia. Yang and Chuang (2012) reported that the highest phenolic content in ethanolic extracts of cinnamon was observed in the bark, followed by the leaves and buds. Cinnamon contained $132.87 \mathrm{CE} \mathrm{mg} / 100 \mathrm{~g}$ of flavonoid compounds, higher than the values reported by Kumar \& Prakash [16] for C. fistula and C. cassia. Prasad [17] reported $98.11 \mathrm{mg} / 100 \mathrm{~g}$ of flavonoids in $50 \%$ ethanol extracts of Chinese C. cassia leaves, while Yang \& Chuang [17] reported $2.030 \mathrm{~g} / 100 \mathrm{~g}$ of the flavonoid content of bark in $95 \%$ ethanolic extracts. The capacity of flavonoids to act as antioxidants depends upon their molecular structure. The position of hydroxyl groups and other features in the chemical structure of flavonoids are important for their antioxidant and free radical scavenging activities [18]. Flavonoids are potent watersoluble antioxidants and free radical scavengers which prevent oxidative cell damage, and they have strong anticancer activity; as antioxidants, flavonoids from spices provide an anti-inflammatory effect [19].

Table 1: Total phenolics, flavonoids, antioxidant activity, and total reducing power of $C$. cassia.

\begin{tabular}{|c|c|c|}
\hline \multicolumn{2}{|c|}{ Parameter } & Value \\
\hline \multicolumn{2}{|c|}{ Total phenolics (mg gallic acid equivalents/100 g) } & $818.73 \pm 2.06$ \\
\hline \multicolumn{2}{|c|}{ Total flavonoids (mg catechin equivalents/100 g) } & $132.87 \pm 2.39$ \\
\hline \multicolumn{2}{|c|}{$\mathrm{DPPH}^{\dagger}$ scavenging activity (\%) } & $80.45 \pm 1.43$ \\
\hline \multicolumn{2}{|c|}{ IC50 Activity } & $8.71 \pm 0.41$ \\
\hline \multirow{4}{*}{ Hydrogen peroxide scavenging activity (\%) } & $1000 \mu \mathrm{L}$ & $59.27 \pm 0.25$ \\
\hline & 500 & $44.30 \pm 0.36$ \\
\hline & 250 & $33.07 \pm 0.21$ \\
\hline & 125 & $24.07 \pm 0.12$ \\
\hline \multirow{4}{*}{ Total reducing power activity $(\mathrm{mM} / \mathrm{mL})$} & $1000 \mu \mathrm{L}$ & $37.77 \pm 0.75$ \\
\hline & 500 & $12.40 \pm 1.10$ \\
\hline & 250 & $4.70 \pm 0.10$ \\
\hline & 125 & $2.13 \pm 0.01$ \\
\hline
\end{tabular}

Values are mean $( \pm \mathrm{SD})$ of triplicate samples. †diphenyl-2-picrylhydrazyl 
As shown in Table 1, the DPPH scavenging activity of C. cassia was $80.45 \%$. Kumar \& Prakash [16], who studied DPPH scavenging activity in four medicinal plants, reported that the highest antioxidant activity $(91.66 \pm 4.33)$ was observed in $C$. fistula followed by C. cassia. This finding is consistent with the previous literature reported by Lin. The $\mathrm{H}_{2} \mathrm{O}_{2}$ scavenging activity of $C$. cassia at various concentrations differed significantly $(\mathrm{P} \leq 0.05) . \mathrm{H}_{2} \mathrm{O}_{2}$ scavenging was found to be $59.27 \%, 44.30 \%, 33.07 \%$, and $24.07 \%$ for 1000,500 , 250 , and $125 \mu \mathrm{l}$ of extract, respectively. Scavenging activity decreased as CP concentration decreased. Similarly, previous study [20] showed a highly positive linear relationship between antioxidant activity and total phenolic content in some spices. Many studies have reported that phenolic compounds in spices and herbs significantly contribute to their antioxidant and pharmaceutical properties [20]. Hydrogen peroxide itself is not very reactive, yet it is sometimes toxic to cells as it may produce hydroxyl radicals. $\mathrm{H}_{2} \mathrm{O}_{2} \mathrm{scavenging}$ activity by extracts may be attributed to their phenolic compounds, which can neutralize $\mathrm{H}_{2} \mathrm{O}_{2}$ to water by electron donation.

Values are mean $( \pm \mathrm{SD})$ of triplicate samples. †diphenyl-2-picrylhydrazyl.

The total reducing power of $C$. cassia extract increased along with $\mathrm{CP}$ concentration, indicating that it is concentration dependent. This result was comparable to that of Kamleshiya [21], who studied the reducing power of aqueous and methanolic C. cassia extracts at different concentrations. The results of the present study indicate that C. cassia extract exhibited high $\mathrm{H}_{2} \mathrm{O}_{2}$ and DPPH scavenging activities and reducing power ability. The overall antioxidant activity of $C$. cassia might be attributed to its phenolic and flavonoid contents as well as other phytochemical constituents.

\section{Antimicrobial Activity of CP Extract}

The antimicrobial activity of aqueous and methanolic $\mathrm{CP}$ extracts against two gram-negative (Escherichia coli ATCC 10536 and Salmonella typhimurium ATCC 14028) and two gram-positive (Staphylococcus aureus ATCC 29737 and Bacillus cereus ATCC 14579) pathogenic bacteria is shown in Table 2. Aqueous C. cassia extract exhibited antibacterial activity against all bacterial strains. The inhibition zone of the aqueous extract was found to be 14.67 and $12.78 \mathrm{~mm}$ for E. coli and S. typhimurium, respectively, and that of the methanolic extract were 18.67 and $17.88 \mathrm{~mm}$, respectively. The penicillin inhibition zone was significantly $(\mathrm{P} \leq 0.05)$ larger than that of aqueous and methanolic extracts against gramnegative bacteria, but comparable to that of the methanolic extract against gram-positive bacteria. The inhibition zone of the aqueous extract was found to be 16.67 and $12.67 \mathrm{~mm}$ for $S$. aureus and $B$. cereus, respectively, and that of the methanolic extract were 20.33 and $14.13 \mathrm{~mm}$, respectively. Again, penicillin exhibited larger zones. The inhibition zone of the methanolic extract, comparable to that of penicillin, was found to be significantly $(\mathrm{P} \leq 0.05)$ larger than that of the aqueous extract for all pathogenic bacteria. This may be due to the extraction of oil with an organic solvent as reported by Huang, who stated that the essential oil from C. cassia bark possessed antibacterial activities against four food spoilage bacteria. These results agree with that reported by Anees [22], who found that methanolic C. cassia extract exhibited antibacterial activity against isolated bacteria.

Table 2: Antimicrobial activity of cinnamon water extracts (CWE), cinnamon methanolic extracts (CME), and penicillin.

\begin{tabular}{|c|c|c|c|}
\hline \multirow{3}{*}{ Bacterial strain } & \multicolumn{3}{|c|}{ Inhibition zone (mm) } \\
\hline & \multicolumn{2}{|c|}{ Cinnamon extracts } & \multirow{2}{*}{ Penicillin $(10 \mu \mathrm{g} / \mathrm{disc})$} \\
\hline & CWE $(10 \mu \mathrm{g} / \mathrm{mL})$ & CME $(10 \mu \mathrm{g} / \mathrm{mL})$ & \\
\hline E. coli ATCC 10536 & $14.67 \pm 0.58^{\mathrm{c}}$ & $18.67 \pm 0.58^{\mathrm{b}}$ & $32.0 \pm 0.09^{\mathrm{a}}$ \\
\hline $\begin{array}{l}\text { Salmonella typhimurium ATCC } \\
14028\end{array}$ & $12.78 \pm 0.61^{\mathrm{c}}$ & $17.88 \pm 0.61^{\mathrm{b}}$ & $19.0 \pm 0.13^{\mathrm{a}}$ \\
\hline Staphylococcus aureus ATCC 29737 & $16.67 \pm 0.54^{\mathrm{c}}$ & $20.33 \pm 0.55^{\mathrm{b}}$ & $24.0 \pm 0.12^{\mathrm{a}}$ \\
\hline Bacillus cereus ATCC 14579 & $12.67 \pm 0.71^{\mathrm{c}}$ & $14.13 \pm 0.47^{\mathrm{b}}$ & $18.0 \pm 0.18^{\mathrm{a}}$ \\
\hline
\end{tabular}

Values are means \pm SD of triplicate samples. Means sharing a different superscript in a row are significantly different at $P \leq 0.05$.

The results of the present study indicated that CP had a great effect on pathogenic bacteria and other food-borne microorganisms and this could be due to antimicrobial mechanisms exhibited by C. cassia bark extract. Similarly, Chaudhry \& Tariq [23] reported that the essential oil extracted from C. cassia bark exhibited antibacterial effects against food borne pathogens such as $S$. aureus, Listeria monocytogenes, Streptococcus oralis, Streptococcus anginosus, and E. coli, and claimed that these antimicrobial properties may come from cinnamaldehyde as well as a variety of other active components.

Table 3: Effects of varying C. cassia levels and refrigerated storage on Sudanese yoghurt (zabadi) physicochemical properties

\begin{tabular}{|c|c|c|c|c|}
\hline \multirow{2}{*}{ C. cassia powder (\%) } & \multicolumn{3}{|c|}{ Storage period (days) } \\
\cline { 2 - 5 } & \multicolumn{3}{|c|}{ Total solids (\%) } \\
\hline 0 & $11.90 \pm 0.14^{\text {bp }}$ & $11.75 \pm 0.07^{\text {bp }}$ & $11.35 \pm 0.07^{\text {bp }}$ \\
\hline 0.5 & $12.25 \pm 0.07^{\text {ap }}$ & $12.10 \pm 0.00^{\text {ap }}$ & $12.05 \pm 0.07^{\text {ap }}$ \\
\hline
\end{tabular}


Journal of Dairy \& Veterinary Sciences

\begin{tabular}{|c|c|c|c|}
\hline 1 & $12.35 \pm 0.07^{\text {ap }}$ & $12.15 \pm 0.57^{\text {ap }}$ & $12.10 \pm 0.07^{\mathrm{ap}}$ \\
\hline \multicolumn{4}{|c|}{ pH-value } \\
\hline 0 & $5.03 \pm 0.01^{\mathrm{cp}}$ & $4.03 \pm 0.06^{\mathrm{bp}}$ & $3.80 \pm 0.02^{\mathrm{aq}}$ \\
\hline 0.5 & $5.30 \pm 0.18^{\text {bp }}$ & $4.04 \pm 0.02^{\mathrm{bq}}$ & $3.89 \pm 0.02^{\mathrm{ar}}$ \\
\hline 1 & $5.56 \pm 0.04^{\text {ap }}$ & $4.30 \pm 0.18^{\text {aq }}$ & $4.01 \pm 0.01^{\mathrm{ar}}$ \\
\hline \multicolumn{4}{|c|}{ Titratable acidity (\%) } \\
\hline 0 & $0.83 \pm 0.00^{\mathrm{ar}}$ & $1.04 \pm 0.08^{\mathrm{aq}}$ & $1.53 \pm 0.12^{\text {ap }}$ \\
\hline 0.5 & $0.84 \pm 0.01^{\text {aq }}$ & $1.01 \pm 0.01^{\mathrm{aq}}$ & $1.29 \pm 0.11^{\mathrm{abp}}$ \\
\hline 1 & $0.85 \pm 0.00^{\text {ap }}$ & $1.03 \pm 0.01^{\text {ap }}$ & $0.93 \pm 0.08^{\text {bp }}$ \\
\hline \multicolumn{4}{|c|}{ Lactose content (\%) } \\
\hline 0 & $3.47 \pm 0.06^{\mathrm{bp}}$ & $3.27 \pm 0.06^{\mathrm{bpq}}$ & $3.20 \pm 0.01^{\mathrm{bq}}$ \\
\hline 0.5 & $4.73 \pm 0.06^{\text {ap }}$ & $4.20 \pm 0.01^{\text {apq }}$ & $3.83 \pm 0.06^{\mathrm{aq}}$ \\
\hline 1 & $4.87 \pm 0.06^{\mathrm{ap}}$ & $4.27 \pm 0.06^{\mathrm{aq}}$ & $3.87 \pm 0.06^{\mathrm{ar}}$ \\
\hline
\end{tabular}

Values are mean \pm SD of triplicate samples. Means sharing a different superscript in a row (p, q, r, s.) or column (a, b, c, ..) are significantly different at $P \leq 0.05$.

Physicochemical Properties of Treated and Untreated Yogurt during Storage

The effects of C. cassia powder concentration and storage period on the physicochemical properties of yogurt (total solids, $\mathrm{pH}$, titratable acidity, and lactose content) are shown in Table 3. Total solids decreased slightly over longer storage periods but increased significantly $(\mathrm{P} \leq 0.05)$ with $\mathrm{CP}$ concentration, reaching $12.35 \%$ prior to storage with little reduction over the total period. The results indicated that the addition of cinnamon increased total yogurt solids alongside cinnamon concentration, although this increase was lower than that reported by El-bakri \& El-zubeir [24]. Sample pH decreased significantly over the storage period, but cinnamon concentration had a significant $(\mathrm{P} \leq 0.05)$ effect on $\mathrm{pH}$, especially at high concentrations, indicating that the addition of $\mathrm{CP}$ at different concentrations may help stabilize yogurt $\mathrm{pH}$.

The titratable acidity of yogurt was significantly $(\mathrm{P} \leq 0.05)$ affected by the storage period and by the concentration of $C$. cassia; it was observed to decrease slightly as cinnamon concentration increased due to increase in $\mathrm{pH}$. Prior to storage, the titratable acidity ranged from 0.83 to 0.85 and increased significantly ( $\mathrm{P} \leq$ 0.05 ) to a range of $0.93-1.53$ after 14 days due to decrease in $\mathrm{pH}$. The results agree with those reported by Eissa [5], who attributed the increase in titratable acidity and decrease in $\mathrm{pH}$ to lactose metabolism and reported that these effects occurred over time during fermentation by LAB. Plain yogurt contained low levels of lactose $(3.47 \%)$ compared to that extended with $0.5 \%$ and $1 \%$. cassia ( $4.73 \%$ and $4.87 \%$, respectively). Lactose content increased significantly $(\mathrm{P} \leq 0.05)$ with cinnamon concentration. However, the decline in lactose level was insignificant $(P \geq 0.05)$ until day 7 of storage, after which it lowered significantly ( $\mathrm{P} \leq 0.05)$, especially in yogurt containing $0.5 \%$ and $1 \%$ C. cassia. The increase in LAB during storage may be responsible for the increase in acid production due to lactose fermentation [5].

\section{Microbial load of Treated and Untreated Yogurt during Storage}

The microbial load of treated and untreated yogurt during storage is shown in Table 4. The results showed that plain yogurt contained the highest bacterial count $(p \leq 0.05)$ for all storage periods, ranging between 4.97 and 7.85. Treatment of yogurt with $0.5 \%$ and $1 \%$ C. cassia powder significantly $(\mathrm{p} \leq 0.05)$ decreased the total viable bacterial count; the highest reduction was observed in the latter sample. The storage period also significantly $(\mathrm{p} \leq 0.05)$ affected the total viable bacterial count in all samples studied. The highest count was found on day 7 of storage, after which it decreased significantly through day 14 for all samples. This could be attributed to increased lactic acid levels produced during the storage period [5].

Table 4: Effect of different levels of $C$. cassia and refrigerated storage on Sudanese yoghurt (zabadi) microbial load.

\begin{tabular}{|c|c|c|c|}
\hline \multirow{2}{*}{ C. cassia powder $(\%)$} & \multicolumn{3}{|c|}{ Storage period (days) } \\
\hline & $\mathbf{0}$ & 7 & 14 \\
\hline \multicolumn{4}{|c|}{ Total viable count of bacteria $\left(\log ^{10} \mathrm{cfu} / \mathrm{g}\right) \dagger$} \\
\hline 0 & $4.97 \pm 0.02^{\mathrm{ar}}$ & $7.85 \pm 0.03^{\text {ap }}$ & $6.69 \pm 0.05^{\text {aq }}$ \\
\hline 0.5 & $1.87 \pm 0.02^{\mathrm{br}}$ & $5.93 \pm 0.03^{\mathrm{bp}}$ & $4.77 \pm 0.04^{\mathrm{bq}}$ \\
\hline 1 & $1.53 \pm 0.05^{\text {cr }}$ & $4.87 \pm 0.02^{\mathrm{cp}}$ & $4.61 \pm 0.04^{\mathrm{bq}}$ \\
\hline \multicolumn{4}{|c|}{ Staphylococcus aureus (log10 cfu/g) } \\
\hline 0 & $2.78 \pm 0.07^{\text {ap }}$ & $2.53 \pm 0.07^{q}$ & ND§ \\
\hline 0.5 & $1.56 \pm 0.07^{\mathrm{bb}}$ & ND & ND \\
\hline
\end{tabular}


Journal of Dairy \& Veterinary Sciences

\begin{tabular}{|c|c|c|c|}
\hline 1 & $1.48 \pm 0.00^{\mathrm{bc}}$ & ND & ND \\
\hline \multicolumn{4}{|c|}{ Total coliforms (MPN/g) } \\
\hline 0 & $22.00 \pm 0.13^{\text {ap }}$ & $14.33 \pm 0.12^{q}$ & ND \\
\hline 0.5 & $14.00 \pm 0.11^{\mathrm{b}}$ & ND & ND \\
\hline 1 & $12.33 \pm 0.07^{c}$ & ND & ND \\
\hline \multicolumn{4}{|c|}{ Escherichia coli (MPN/g) } \\
\hline 0 & $3.33 \pm 0.04^{\mathrm{a}}$ & ND & ND \\
\hline 0.5 & $1.00 \pm 0.10^{\mathrm{b}}$ & ND & ND \\
\hline 1 & ND & ND & ND \\
\hline \multicolumn{4}{|c|}{ lactic acid bacteria } \\
\hline \multicolumn{4}{|c|}{ Streptococcus thermophilus $\left(\log ^{10} \mathrm{cfu} / \mathrm{g}\right)$} \\
\hline 0 & $2.69 \pm 0.09^{\text {cr }}$ & $5.70 \pm 0.04^{\text {bp }}$ & $4.53 \pm 0.05^{\mathrm{bq}}$ \\
\hline 0.5 & $3.73 \pm 0.03^{\mathrm{br}}$ & $6.87 \pm 0.02^{\text {ap }}$ & $5.53 \pm 0.05^{\text {aq }}$ \\
\hline 1 & $4.51 \pm 0.03^{\mathrm{ar}}$ & $6.74 \pm 0.02^{\text {ap }}$ & $5.51 \pm 0.03^{\text {aq }}$ \\
\hline \multicolumn{4}{|c|}{ Lactobacillus spp. $\left(\log ^{10} \mathrm{cfu} / \mathrm{g}\right)$} \\
\hline 0 & $2.52 \pm 0.07^{\mathrm{br}}$ & $3.81 \pm 0.03^{\text {bq }}$ & $3.59 \pm 0.11^{\mathrm{cp}}$ \\
\hline 0.5 & $2.63 \pm 0.06^{\mathrm{br}}$ & $5.81 \pm 0.03^{\text {bp }}$ & $4.63 \pm 0.03^{\mathrm{bq}}$ \\
\hline 1 & $3.65 \pm 0.04^{\mathrm{ar}}$ & $5.90 \pm 0.03^{\text {ap }}$ & $5.06 \pm 0.03^{\text {aq }}$ \\
\hline
\end{tabular}

Values are mean $\pm S D$ of triplicate samples. Means sharing a different superscript in a row $(p, q, r, s, .$.$) or column (a, b, c, .$.$) are significantly$ different at $\mathrm{P} \leq 0.05$. †Cfu, colony forming units; $¥ \mathrm{MPN}$, most probable number; §ND, not detected.

As shown in Table 4, the $S$. aureus count in untreated yogurt was $2.78 \mathrm{cfu} / \mathrm{g}$. Addition of 0.5 and $1 \%$ C. cassia significantly decreased the count to 1.56 and 1.48 , respectively. The results showed that the $S$. aureus count decreased with increased $C$. cassia concentration. The storage period was also found to affect the S. aureus count; it dropped to 2.53 after 7 days and disappeared completely on day 14 in the control sample. The disappearance of $S$. aureus could be due to the reduction in $\mathrm{pH}$ as well as competitive growth of other micro-organisms such as lactic acid bacteria which had inhibitory effect on S. aureus growth [25]. The presence of $S$. aureus indicated that milk could be contaminated during handling. Samples treated with either amount of $C$. cassia showed a negative $S$. aureus count in the two storage periods, possibly due to the antimicrobial action of $C$. cassia powder.

The coliform count in untreated yogurt was $22.00 \mathrm{MPN} / \mathrm{g}$. The addition of $0.5 \%$ and $1 \%$ C. cassia significantly ( $\mathrm{p} \leq 0.05$ ) decreased the coliform count to 14.00 and $12.33 \mathrm{MPN} / \mathrm{g}$, respectively. Coliform presence could be attributed to milk contamination during handling. The results showed that coliform count decreased significantly $(\mathrm{p} \leq 0.05)$ as $C$. cassia concentration increased. This may indicate the antimicrobial effect of $C$. cassia powder in yogurt. The storage period was found to affect coliform count, which dropped significantly ( $\mathrm{p} \leq 0.05$ ) to 14.33 by day 7 of storage and disappeared completely on day 14 in the control sample due to increase in lactic acid. Samples treated with $0.5 \%$ and $1 \%$ C. cassia powder showed null coliform counts during the two storage periods ( 7 and 14 days) investigated. The $E$. coli count in untreated yogurt was $3.33 \mathrm{MPN} / \mathrm{g}$ and dropped significantly ( $\mathrm{p}$ $\leq 0.05$ ) to 1 and 0 for samples treated with $0.5 \%$ and $1 \%$ C. cassia, respectively, clearly indicating an inhibitory effect on yogurt $E$. coli by cinnamon. The storage period significantly ( $\mathrm{P} \leq 0.05$ ) affected the $E$. coli count in yogurt. All samples studied showed no $E$. coli growth during the storage periods investigated 7 and 14 days). Again, the absence of coliform bacteria and E. coli in treated samples could be due to the microbial action of $C$. cassia resulting from its phytochemicals compounds such as flavonoids and phenolics.

In general, LAB (Streptococcus and Lactobacillus) increased significantly ( $\mathrm{p} \leq 0.05)$ with both $C$. cassia concentration and storage period, as shown in Table 4. Generally, Streptococcus was dominant compared to Lactobacillus in plain and treated yogurt, even during storage. Treatment of yogurt with $0.5 \%$ and $1 \%$ C. cassia significantly ( $\mathrm{P} \leq 0.05)$ increased the Streptococcus count, indicating that the addition of cinnamon improves LAB availability to reach acceptable levels. The storage period also significantly $(\mathrm{P} \leq 0.05)$ affected the Streptococcus count in all samples studied. The count was highest on day 7 , after which it decreased significantly $(p \leq 0.05)$ in all samples. This could be attributed to the reduction of nutrients in yogurt or the increase of bacterial lactic acid production. The significant drop by day 14 in viable S. thermophilus cell counts in cow milk yogurt may be attributed to the accumulation of organic acids. Treatment of yogurt with $0.5 \%$ and $1 \%$ C. cassia significantly ( $\mathrm{P} \leq 0.05$ ) increased the Lactobacillus count, with the highest observed in the latter samples. These results were similar to previous findings by Eissa [5], who reported that fermentation improved proteolytic activity and enhanced LAB growth in cow and goat milk. The increase in Lactobacillus count lies within the acceptable level 
(106). The storage period also significantly $(P \leq 0.05)$ affected the Lactobacillus count in all samples studied. The peak count was found on day 7 , after which it decreased significantly ( $P \leq 0.05$ ) in all samples. This result agreed with a previous study that found refrigerated storage significantly decreased the viable counts of Lactobacillus spp. by day 14 of refrigerated storage. Additionally, the reduction in Lactobacillus spp. counts could be associated with the post-acidification of yogurt, which further reduces $\mathrm{pH}$ [5].

\section{Effects of different C. cassia levels on Sensory Evaluation of Yogurt}

The effect of $C$. cassia powder on the final characteristics of the yoghurt was evaluated by sensory analysis on samples at day 0 and during refrigerated storage until day 14 (Table 5). Twenty panelists were asked to score color, flavor, texture, taste and overall acceptability. During storage, the levels of the sensory attributes of yoghurt were higher when $\mathrm{CP}$ was added. All panelists evaluated the plain yoghurt as less consistent and more acid compared to the yoghurt containing $\mathrm{CP}$. This result could be attributed to the low microbiological quality of the raw milk; in fact, although pasteurization decreased the levels of TMM, the metabolites of the indigenous microorganisms that grew before thermal treatment could have impacted this aspect. On the contrary, CP odors might have limited perception of such traits. Microbial hydrolysis of yoogurt component during storage was found to be the key deteriorating factor with regard to taste, color, flavor and texture [26]. The most notable differences between the control and $\mathrm{CP}$ yoghurt were observed for color and flavor intensity. In general, the data obtained suggested that color, flavor and texture were the three most important parameters reflecting the overall acceptability of yoghurt containing $\mathrm{CP}$. Regarding texture, the control yoghurt showed a decrease of the values with storage, while CP yoghurt showed almost increasing levels. Similar results were observed in yoghurt manufactured from goat's milk [26].

Table 5: Effect of varying C. cassia levels on sensory evaluation of refrigerated Sudanese yoghurt (zabadi).

\begin{tabular}{|c|c|c|c|}
\hline \multirow{2}{*}{$\begin{array}{l}\text { Quality attributes/ storage } \\
\text { period }\end{array}$} & \multicolumn{3}{|c|}{ C. cassia powder $(\%)$} \\
\hline & $\mathbf{0}$ & 0.5 & 1 \\
\hline \multicolumn{4}{|c|}{ Color } \\
\hline 0 & $6.65 \pm 0.59^{\text {ap }}$ & $5.25 \pm 1.33^{\mathrm{aq}}$ & $5.30 \pm 1.23^{\mathrm{bq}}$ \\
\hline 7 & $5.53 \pm 0.23^{\mathrm{bq}}$ & $5.66 \pm 0.45^{\text {aq }}$ & $6.03 \pm 0.73^{\text {ap }}$ \\
\hline 14 & $5.25 \pm 0.31^{\text {bp }}$ & $5.78 \pm 0.83^{\text {ap }}$ & $5.91 \pm 0.46^{\mathrm{ap}}$ \\
\hline \multicolumn{4}{|c|}{ Flavor } \\
\hline 0 & $6.00 \pm 0.79^{\text {ap }}$ & $5.25 \pm 1.05^{\mathrm{bq}}$ & $5.10 \pm 1.17^{\mathrm{bq}}$ \\
\hline 7 & $5.80 \pm 0.47^{\mathrm{aq}}$ & $6.01 \pm 0.33^{\mathrm{aq}}$ & $6.84 \pm 0.35^{\text {ap }}$ \\
\hline 14 & $5.55 \pm 0.34^{\text {bq }}$ & $6.23 \pm 0.79^{\text {ap }}$ & $6.76 \pm 0.29^{\mathrm{ap}}$ \\
\hline \multicolumn{4}{|c|}{ Texture (viscosity) } \\
\hline 0 & $5.80 \pm 0.76^{\text {ap }}$ & $5.65 \pm 1.00^{\mathrm{bq}}$ & $5.75 \pm 1.03^{\text {bq }}$ \\
\hline 7 & $5.67 \pm 0.27^{\text {bp }}$ & $5.85 \pm 0.88^{\text {ap }}$ & $5.91 \pm 0.53^{\mathrm{bp}}$ \\
\hline 14 & $5.54 \pm 0.46^{\mathrm{ap}}$ & $6.05 \pm 0.56^{\mathrm{aq}}$ & $6.18 \pm 0.63^{\mathrm{aq}}$ \\
\hline \multicolumn{4}{|c|}{ Taste (acidity) } \\
\hline 0 & $5.55 \pm 0.54^{\text {ap }}$ & $6.20 \pm 0.49^{\mathrm{ap}}$ & $6.01 \pm 0.35^{\text {ap }}$ \\
\hline 7 & $5.25 \pm 0.44^{\mathrm{ap}}$ & $6.56 \pm 0.21^{\text {ap }}$ & $6.05 \pm 1.05^{\mathrm{ap}}$ \\
\hline 14 & $5.05 \pm 0.32^{\text {ap }}$ & $6.81 \pm 0.66^{\mathrm{ap}}$ & $6.02 \pm 0.55^{\mathrm{ap}}$ \\
\hline \multicolumn{4}{|c|}{ Overall acceptability } \\
\hline 0 & $5.25 \pm 0.99^{\text {ap }}$ & $5.35 \pm 0.67^{\mathrm{bq}}$ & $5.46 \pm 1.06^{\mathrm{bq}}$ \\
\hline 7 & $5.15 \pm 0.22^{\mathrm{br}}$ & $5.75 \pm 0.32^{\mathrm{bq}}$ & $5.46 \pm 0.36^{\text {bp }}$ \\
\hline 14 & $5.01 \pm 0.23^{\mathrm{br}}$ & $5.89 \pm 0.27^{\mathrm{bp}}$ & $5.38 \pm 0.38^{\mathrm{aq}}$ \\
\hline
\end{tabular}

Values are mean $\pm S D$ of triplicate samples. Means sharing a different superscript in a row $(p, q, r, s, .$.$) or column (a, b, c, .$.$) are significantly$ different at $P \leq 0.05$.

\section{Conclusion}

C. cassia exhibits significant antioxidant and antibacterial activities and maintains LAB at acceptable levels. The use of $C$. cassia bark powder in yogurt resulted in significantly decreased acidity with an increase in concentration, improved product taste, delayed yogurt acidity, and reduced total coliform count and total viable counts of E. coli and S. aureus. C. cassia powder can be utilized as a functional additive to preserve food against pathogens and extend shelf life. The results of this investigation highlighted the possibility of processing yogurt with $C$. cassia.

\section{Conflict of Interest}

The authors declare that they have no conflict of interest. 


\section{References}

1. Carlsen MH, Halvorsen BL, Holte K, Bohn SK, Dragland S, et al. (2010) The total antioxidant content of more than 3100 foods, beverages, spices, herbs and supplements used worldwide. Nutrition Journal 9: 3-8.

2. Nabavi S, Di Lorenzo A, Izadi M, Sobarzo-Sánchez E, Daglia M (2015) Antibacterial effects of cinnamon: From farm to food, cosmetic and pharmaceutical industries. Nutrients 7: 7729-7748.

3. Yeh HF, Luo CY,Lin CY, Cheng SS, Hsu YR, etal. (2013) Methods for thermal stability enhancement of leaf essential oils and their main constituents from indigenous cinnamon (Cinnamomum osmophloeum). Journal of Agricultural and Food Chemistry 61: 6293-6298.

4. Bandara T, Uluwaduge I, Jansz ER (2012) Bioactivity of cinnamon with special emphasis on diabetes mellitus: a review. International Journal of Food Sciences and Nutrition 63: 380-386.

5. Eissa EA, Babiker EE, Yagoub AEA (2011) Physicochemical, microbiological and sensory properties of Sudanese yoghurt (zabadi) made from goat's milk. Animal Production Science 51: 53-59.

6. Madaan R, Bansal G, Kumar S, Sharma A (2011) Estimation of total phenols and flavonoids in extracts of Actaea spicata roots and antioxidant activity studies. Indian Journal of Pharmaceutical Sciences 73: 666-671.

7. Kim DO, Jeong SW, Lee CY (2003) Antioxidant capacity of phenolic phytochemicals from various cultivars of plums. Food Chemistry 81: 321-326.

8. Lee SK, Mbwambo ZH, Chung H, Luyengi L, Gamez EJ, et al. (1998) Evaluation of the antioxidant potential of natural products. Combinatorial Chemistry and High Throughput Screening 1: 35-46.

9. Oyaizu M (1986) Studies on product of browning reaction prepared from glucose amine. Japanese Journal of Nutrition 44: 307-315.

10. Jayaprakasha GK, Rao LJ, Sakariah KK (2004) Antioxidant activities of flavidin in different in vitro model systems. Bioorganic and Medicinal Chemistry 12: 5141-5146.

11. AOAC (2003) Official Methods of Analysis of AOAC International, (17 edn), AOAC International, Gaithersburg, USA.

12. Bradley RL, Arnold JE, Barbano JD, Semerad RG, Smith DE, et al (1992) Chemical and physical method: In Standard Method for the Examination of Dairy Products. Marshall RT (Eds.), American Public Health Association (APHA). New York, USA, pp. 433-439.

13. Teles FF, Young CK, Stull JW (1978) A Method for Rapid Determination of Lactose 1, 2. Journal of Dairy Science 61: 506-508.
14. Boyanova L, Gergova G, Nikolov R, Derejian S, Lazarova E, et al. (2005) Activity of Bulgarian propolis against 94 Helicobacter pylori strains in vitro by agar-well diffusion, agar dilution and disc diffusion methods. Journal of Medical Microbiology 54: 481-483.

15. Harrigan WF (1998) Laboratory methods in food microbiology. ( $3^{\text {rd }}$ edn), Academic press, California, USA, pp. 533-540.

16. Kumar U, Prakash V (2012) Comparative analysis of antioxidant activity and phytochemical screening of some Indian medicinal plants. International Journal of Pharmacy and Pharmaceutical Sciences 4: 291-295.

17. Prasad KN, Yang B, Dong X, Jiang G, Zhang H, et al. (2009) Flavonoid contents and antioxidant activities from Cinnamomum species. Innovative Food Science and Emerging Technologies 10: 627-632.

18. Yang C, Li R, Chuang L (2012) Antioxidant activity of various parts of Cinnamomum cassia extracted with different extraction methods. Molecules 17: 7294-7304.

19. Okwu DE (2004) Phytochemical and vitamin content of indigenous spices of South Eastern Nigeria. Journal of Sustainable Agriculture and the Environment 6: 30-37.

20. Shan B, Cai YZ, Sun M, Corke H (2005) Antioxidant capacity of 26 spice extracts and characterization of their phenolic constituents. Journal of Agricultural and Food Chemistry 53: 7749-7759.

21. Kamleshiya P, Meshram VG, Ansari AH (2012) Comparative evaluation of antioxidant and free-radical scavenging activity of aqueous and methanolic spice extracts. International Journal of Life Science and Pharma Research 2: 118-125.

22. Anees Ahmed M, Ravi S and Ghogare P (2015) Studies on antimicrobial activity of spices and effect of temperature and $\mathrm{pH}$ on its antimicrobial properties. IOSR Journal of Pharmacy and Biological Sciences 10: 99102 .

23. Chaudhry NMA, Tariq P (2006) Anti-microbial activity of Cinnamomum cassia against diverse microbial flora with its nutritional and medicinal impacts. Pakistan Journal of Botany 38: 169-174.

24. El-Bakri JM, El-Zubeir IE (2009) Chemical and microbiological evaluation of plain and fruit yoghurt in Khartoum State, Sudan. International Journal of Dairy Science 4: 1-7?

25. Charlier C, Cretenet M, Even S, Le Loir Y (2009) Interactions between Staphylococcus aureus and lactic acid bacteria: an old story with new perspectives. International Journal of Food Microbiology 131: 30-39.

26. Duboc P, Mollet B (2001) Applications of exopolysaccharides in the dairy industry. International Dairy Journal 11: 759-768.

\section{Your next submission with Juniper Publishers will reach you the below assets}

- Quality Editorial service

- Swift Peer Review

- Reprints availability

- E-prints Service

- Manuscript Podcast for convenient understanding

- Global attainment for your research

- Manuscript accessibility in different formats

( Pdf, E-pub, Full Text, Audio)

- Unceasing customer service

Track the below URL for one-step submission https://juniperpublishers.com/online-submission.php 